\title{
Struktur dan Fungsi Sosial Nyanyian Rakyat (Lullaby) "Laloklah Nak Kanduang" Masyarakat di Nagari Paninggahan
}

\author{
Winda Oktania Sari ${ }^{1, *}$ Hasanuddin WS ${ }^{2}$ \\ 1,2 Universitas Negeri Padang \\ Jalan Prof. Dr. Hamka, Padang, Sumatera Barat \\ *Corresponding author. Email: Windaoktaniasari123@gmail.com
}

\begin{abstract}
This research was conducted with the aim of describing the structure and social function of the folk song (lullaby) of Laloklah Nak Kanduang community in Nagari Paninggahan, Junjung Sirih District, Solok Regency. This type of research is qualitative with descriptive methods. Data obtained from informants through recording, recording, observation, and direct interviews with informants. Then the data that has been collected is analyzed in the following stages: (1) the data identification stage, (2) the data analysis stage, (3) the discussion stage and the conclusion of the data classification results, (4) the reporting stage. Laloklah Nak Kanduang's song has a structure like that found in poetry, namely physical structure (lines, stanzas, and sounds) and inner structure (patterns of association, patterns of images and emotions as well as themes and messages). Then the social functions, namely three (1) creative functions, (2) enthusiasm, (3) hope and prayer. The oral tradition of humming needs to be preserved, considering that the values contained in chanting are priceless cultural assets.
\end{abstract}

Key words. structure, social function, folksong, Laloklah Nak Kanduang, Nagari Paninggahan.

Abstrak. Penelitian ini dilakukan dengan tujuan untuk mendeskripsikan tentang struktur dan fungsi sosial nyanyian rakyat (lullaby) Laloklah Nak Kanduang masyarakat di Nagari Paninggahan Kecamatan Junjung Sirih Kabupaten Solok. Jenis penelitian ini adalah kualitatif dengan metode deskriptif. Data didapat dari informan melalui teknik perekaman, pencatatan, pengamatan, dan wawancara langsung dengan informan. Kemudian data yang telah dikumpulkan dianalisis dengan tahap sebagai berikut: (1) tahap identifikasi data, (2) tahap analisis data, (3) tahap pembahasan dan penyimpulan hasil klasifikasi data, (4) tahap pelaporan. Nyanyian Laloklah Nak Kanduang memiliki struktur seperti yang terdapat dalam puisi, yaitu struktur fisik (baris, bait, dan bunyi) serta struktur batin (pola asosiasi, pola-pola citraan dan emosi serta tema dan amanat). Kemudian fungsi sosial, yaitu tiga (1) fungsi kreatif, (2) pembangkit semangat, (3) harapan dan doa. Tradisi lisan bersenandung, perlu dilakukan dilestarikan, mengingat nilai-nilai yang terkandung dalam senandung merupakan aset budaya yang tak ternilai harganya.

Kata kunci. struktur, fungsi sosial, nyanian rakyat, Laloklah Nak Kanduang, Nagari Paninggahan.

\section{Pendahuluan}

Folklor merupakan salah satu bentuk kebudayaan dan tradisi masyarakat yang telah lama ada di Indonesia. Dari segi bentuknya, folklor terbagi menjadi folklor lisan, folklor sebagian lisan, dan folklor bukan lisan. Kebudayaan lisan ialah salah satu bentuk folklor sebagian lisan yang 
diturunkan secara turun-temurun dari mulut ke mulut, yaitu dari orang tua pada zaman dahulu sampai kepada anak cucunya sekarang. Folklor sebagian lisan termasuk nyanyian rakyat yang masih berkembang di masyarakat Indonesia hingga saat ini.

Hasanuddin WS, Emidar, Zulfadhli (2020, p. 638) menyebutkan bahwa masyarakat suku Minangkabau merupakan salah satu etnis yang kuat dan eksis di Nusantara. Identitas keaslian Minangkabau turut membentuk kebudayaan nasional antara lain melalui bahasa, kesenian, dan aspek tradisi lainnya. Teeuw (1989) menjelaskan bahwa sepanjang pelisan karya sastra modern Indonesia yang ditulis oleh pengarang yang berasal dari Minangkabau sarat dengan muatan penentang kaum muda terhadap budaya Minangkabau. Sastrawan Minangkabau mengusung persoalan sosial budaya sebagai tema karya mereka dengan memperihatkan corak kebudayaan etnisnya. Masyarakat yang kuat dan mampu menyumbangkan budayanya adalah sekelompok orang yang kuat, kompak, dan bangga dengan jati dirinya. Masyarakat seperti itu tumbuh karena memiliki faktor "perekat". Perekat tersebut tentunya dari nilai-nilai fundamental yang dapat mengintegrasikan masyarakat Minangkabau ke dalam suatu kesatuan pola hidup (pandangan, nilai-nilai kehidupan, filosofi, dan lainnya).

Sastra lisan terdiri atas nyanyian penyemangat kerja (working song), nyanyian permainan rakyat (game song), dan nyanyian senandung menidurkan anak (lullaby). Menurut Brunvand (dalam Danandjaya, 1991, p. 141), nyanyian rakyat adalah salah satu genre atau bentuk folklor yang terdiri atas kata-kata dan lagu yang diedarkan secara lisan di antara kolektif tertentu berbentuk tradisional serta banyak varian. Nyanyian rakyat juga memiliki fungsi, yaitu nyanyian rakyat yang kata-katanya memiliki peranan dan maksud penting. Karena lirik lagunya sesuai dengan aktivitas kehidupan manusia pada umumnya. Namun kali ini, peneliti akan melakukan penelitian mengenai nyanyian rakyat menidurkan anak (lullaby). Hasanuddin WS et. al. (2020, p. 147) berpendapat bahwa studi tentang sastra lisan lagu pengantar tidur membuat anak tertidur telah banyak dilakukan oleh para peneliti baik dari lirik atau teks lagu maupun studi tentang lagu pengantar tidur.

Salah satu daerah yang berada di Sumatera Barat ialah Nagari Paninggahan Kecamatan Junjung Sirih Kabupaten Solok. Nagari Paninggahan berada di antara Malalo dan Muaro Pingai. Umumnya masyarakat yang tinggal di paninggahan memakai logat asli Nagari Paninggahan (Badan Pusat Statistik Kabupaten Solok). Mata pencaharian yang umum di Nagari Paninggahan adalah bercocok tanam. Umumnya, saat si Ibu pergi ke sawah, anak akan ditinggalkan atau dititipkan kepada neneknya di rumah. Untuk membuat si anak merasa nyaman, sang nenek menyanyikan berbagai senandung untuk menidurkan anak (lullaby).

Senandung Laloklah Nak Kanduang (selanjutnya LNK) merupakan salah satu nyanyian rakyat yang terdapat di nagari Paninggahan. Senandung LNK berfungsi untuk menidurkan anak saat di rumah yang mana dalam lirik atau syairnya mengandung harapan-harapan dan doa yang diharapkan oleh seorang ibu atau nenek kepada anak atau cucunya, sambil mengayun anak di dalam kain panjang atau di ayunan. Melalui tradisi mendendangkan ini, masyarakat Minangkabau dapat dengan bebas mengekspresikan dan menumpahkan perasaan, harapan dan doa-doanya yang dinyanyikan kepada anaknya.

Penelitian ini menarik untuk diteliti karena nyanyian senandung menidurkan anak ini semakin hari semakin kurang diminati. Hal ini sedikit banyak dipengaruhi oleh pola kehidupan modern dan kemajuan teknologi yang pesat. Sehingga, nyanyian rakyat senandung menidurkan anak (lullaby) saat ini hanya diketahui oleh masyarakat yang hidup dalam zaman-zaman terdahulu dan sekarang sudah berusia lanjut. Minat dan keingintahuan generasi muda sekarang dinilai masih sangat rendah bahkan mereka bersikap acuh tak acuh terhadap tradisi yang ada di daerahnya 
masing-masing. Dengan demikian, penelitian ini dilakukan untuk mendokumentasikan dan memperkenalkan serta untuk mengetahui gambaran jelas tentang nyanyian rakyat (Lullaby) yang ada di Nagari Paninggahan bertujuan untuk membudidayakan tradisi nyanyian rakyat (Lullaby) Masyarakat di Nagari Paninggahan Kecamatan Junjung Sirih Kabupaten Solok.

Penelitian yang berkaitan dengan nyanyian rakyat/lullaby Senandung Malalokan Anak adalah pertama penelitian yang dilakukan oleh Al-Afandi (2015) dengan judul "Fungsi dan Nilai Nyanyian Buaian dalam Sastra Lisan Kaili". Dalam hasil penelitiannya, Afandi menjelaskan tentang fungsi nyanyian Buaian Kaili yang terdiri dari fungsi informasi, fungsi edukatif, fungsi perintah dan hiburan serta nilai-nilai yang terkandung dalam nyanyian Buaian dalam sastra lisan Kaili.

Penelitian relevan kedua adalah penelitian yang dilakukan Rukiyah (2018) dengan judul "Aspek Pendidikan Nyanyian Kelonan", dimana dalam hasil penelitiannya mendeskripsikan aspek pendidikan lagu kelonan. Dari hasil penelitian tersebut, dikatakan bahwa tradisi menyanyikan anak perlu dilestarikan karena merupakan warisan budaya nenek moyang. Nyanyian kelonan yang berirama halus dan tenang sangat cocok dipakai sebagai media untuk menidurkan anak. Selain itu, nyanyian kelonan berfungsi sebagai sarana pendidikan karena lirik lagu kelonan kebanyakan berisi doa dan nasihat.

Penelitian relevan ketiga adalah penelitian yang dilakukan oleh Fitriani (2020) dengan judul "Struktur dan Fungsi Sosial Nyanyian Rakyat Senandung (Lullaby) Ende Bue-bue Masyarakat Desa Sarimanaon Kecamatan Angkola Muara Tais Kabupaten Tapanulis Selatan”, dimana dalam hasil penelitiannya menjelaskan tentang stuktur yang terdapat pada senanandung lullaby Ende Bue-bue yang ditinjau dari segi struktur fisik maupun struktur batin dan fungsi sosial senandung lullaby "Ende Bue-bue".

\section{Metode}

Jenis penelitian ini adalah penelitian kualitatif. Menurut Moleong (2005), penelitian kualitatif adalah penelitian yang bermaksud untuk memahami fenomena tentang apa yang dialami oleh subjek penelitian misalnya perilaku, persepsi, motivasi, tindakan, dan dengan cara deskripsi dalam bentuk kata-kata dan bahasa, pada suatu konteks khusus yang alamiah dan dengan memanfaatkan berbagai metode alamiah. Data dalam penelitian ini yaitu, mengenai nyanyian rakyat (lullaby) senandung menidurkan anak masyarakat Nagari Paninggahan di Kecamatan Junjung Sirih, Kabupaten Solok, Provinsi Sumatera Barat. Penelitian ini tergolong penelitian kualitatif Karena penelitian ini dilakukan tidak menggunakan angka-angka akan tetapi menggunakan pendalaman dan penghayatan mengenai interaksi tentang konsep yang dibahas.

Metode penelitian yang digunakan dalam penelitian ini adalah metode deskriptif analisis. Penelitian ini tegolong kepada penelitian deskriptif karena bersifat memaparkan data-data yang berupa uraian kata-kata bukan dengan angka. Data yang dikumpulkan melalui penelitian ini adalah metode deskriptif analisis pekerjaan dan aktivitas. Menurut Nazir (1988) penelitian analisa pekerjaan dan aktivitas merupakan penelitian yang ditujukan untuk menyelidiki secara terperinci aktivitas dan pekerjaan manusia, dan hasil penelitian tersebut dapat memberikan rekomendasirekomendasi untuk keperluan masa yang akan datang. Dalam hal ini, metode deskriptif analisa berarti bukan hanya melakukan deskripsi murni, melainkan juga menetapkan arti, dan menarik kesimpulan. Dengan demikian, metode ini berusaha pula mendeskripsikan fakta secara logis. Data ini pada umumnya berupa pencatatan, foto-foto, rekaman, dokumen, dan catatan resmi lainnya. Melalui metode, pendeskripsian data dilakukan dengan cara menunjukkan fakta-fakta yang berhubungan dengan struktur nyanyian, dilanjutkan dengan penganalisisan struktur fisik dan batin 
dan dilengkapi dengan pendeskripsian fungsi sosial yang terdapat dalam nyanyian rakyat (lullaby) senandung menidurkan anak masyarakat Nagari Paninggahan Kecmatan Junjung Sirih Kabupaten Solok Provinsi Sumatera Barat.

Data yang diperolah selanjutnya akan dianalisis berdasarkan teori tentang struktur dan fungsi nyanyian rakyat (lullaby) di Nagari Paninggahan Kecmatan Junjung Sirih Kabupaten Solok Provinsi Sumatera Barat. Penelitian ini dilakukan melalui beberapa tahap analisis, yaitu (1) tahap klasifikasi atau analisis data, data yang diperoleh melalui tahap inventarisasi selanjutnya diklasifikasikan berdasarkan teori yang telah ditetapkan, (2) tahap pembahasan dan penyimpulan hasil klasifikasi atau analisis data, data yang telah diklasifikasi atau dianalisis melalui tahap klasifikasi atau hasil analisis data, selanjutnya dibahas apakah hasil klasifikasi atau analisis data terhadap data sesuai dengan kerangka teori atau tidak. Jika tidak sesuai, apakah ketidaksesuaian itu hanya pada perbedaan varian atau variasi saja atau bertentangan dengan teori yang telah ada, (3) tahap pelaporan, melaporkan seluruh hasil tahapan analisis data dalam bentuk laporan deskriptif dan dalam bentuk laporan hasil penelitian berupa skripsi.

\section{Hasil dan Pembahasan}

\section{Struktur Fisik Nyanyian Rakyat Senandung (Lullaby) Laloklah Nak Kanduang}

\section{Baris}

Baris pada sebuah kalimat berbeda dengan baris yang ada di dalam prosa, yaitu bias satu kata, bias frase, dan kalimat. Pada pantun atau puisi lama, jumlah kata pada larik biasanya empat kata, tetapi pada puisi baru tidak ada batasan kata atau lariknya. Keseluruhan data teks nyanyian rakyat (lullaby) Laloklah Nak Kanduang memiliki dua puluh dua baris yang terdiri dari enam bait. Jumlah kata dalam setiap baris dalam larik nyanyian rakyat (lullaby) sangat beragam, yaitu dua, tiga, empat, lima, enam, dan tujuh kata dalam satu barisnya. Dapat dilihat pada contoh berikut ini pada teks nyanyian rakyat (lullaby) Laloklah Nak Kanduang terdapat empat baris, dua baris dalam satu bait. Jumlah kata dalam setiap bait beragam mulai dari enam, sampai dengan tujuh belas kata per bait.

(D01) Laloklah nak, lalok babuwai

Piciangan mato mande buwai

Jan manangih juo nak

Mande ka pai karajo nak

'Tidurlah nak, tidur berayun

Pejamkan mata ibu ayun

Jangan menangis juga nak

Ibu mau pergi kerja nak'

(D06)Usah manangih

Beko mande pulang juo

Jangan menangis

Nanti ibu pulang juga'

Keseluruhan data teks nyanyian rakyat (lullaby) Laloklah Nak Kanduang memiiki dua puluh dua baris yang terbagi atas enam belas bait yang terdiri atas empat baris salah satunya dapat dilihat pada (D01), satu bait dengan dua baris dapat dilihat pada (D06). Pada keseluruhan data 
terdapat beberapa ragam baris pada baitnya. Secara keseluruhan teks nyanyian rakyat (lullaby) Laloklah Nak Kanduang memiliki empat baris setiap baitnya.

\section{Bait}

Bait merupakan dari teks berirama (syair, puisi, dan lagu). Bait juga merupakan homograf dalam bahasa Indonesia, yaitu sebuah kata yang penulisannya sama tetap arti dan pelafalannya berbeda. Biasanya satu bait pada syair atau pada larik terdiri atas empat baris atau lebih. Bait mempunyai fungsi memisahkan topik-topik atau ide-ide yang diekspresikan dalam suatu syair dan larik. Namun jumlah baris dalam bait nyanyian rakyat (lullaby) Laloklah Nak Kanduang tidak semua yang berjumlah empat baris dalam satu bait, ada yang dua baris dalam satu bait.

(D06)Usah manangih

Beko mande pulang juo

'Jangan menangis

Nanti ibu pulang juga'

Dari keseluruhan teks nyanyian rakyat (lullaby) Laloklah Nak Kanduang terdiri atas enam bait. Pada (D06) merupakan bait yang jumlah barisnya dua baris.

\section{Bunyi}

Puisi maupun syair memliki sifat estetik, yaitu unsur untuk mendapatkan keindahan. Bunyi memiliki hubungan dengan erat dengan music seperti lagu, melodi, dan irama. Selain memperindah puisi maunpun syair, bunyi juga memiliki peranan yang lebih penting, yaitu untuk memperdalam ucapan, menimbulkan baying-bayang yang jelas, serta menimbulkan suasana yang khusus.

Pada teks nyanyian rakyat (lullaby) Laloklah Nak Kanduang terdapat rima berpola ab-ab, aabb, dan aa-aa seperti contoh teks Laloklah Nak Kanduang berikut.

$\left.\begin{array}{l}\text { (D01) Laloklah nak, lalok babuwai } \\ \text { Capeklah gadang nak ooo } \\ \text { Usah banyak parangai } \\ \text { Alah mande buwai pulo }\end{array}\right\} a b-a b$

'Tidurlah nak, tidur berayun

Cepatlah besar nak ooo

Jangan banyak tingkah laku

Sudah ibu ayun pula'

Rima yang ditemukan pada teks nyanyian rakyat (lullaby) Laloklah Nak Kanduang adalah rima ab-ab pada (D01). Pada teks nyanyian rakyat (lullaby) Laloklah Nak Kanduang terdapat pengulangan bunyi berbentuk aliterasi dan asonansi, dapat dilihat pada data berikut ini.

(D01) Laloklah nak, lalok babuwai

Jan manangih juo nak

Piciangan mato mande buwai

Mande ka pai karajo nak 
'Tidurlah nak, tidur berayun

Jangan menangis juga nak

Pejamkan mata ibu ayun

Ibu mau pergi kerja nak'

Aliterasi merupakan pengulangan huruf mati pada beberapa suku kata yang berturutturut. Pada teks Laloklah Nak Kanduang (D08) di atas terlihat pada pengulangan bunyi yang dominan, yaitu bunyi k, o, j, dan $\mathrm{m}$ dalam beberapa baris. Seperti pada kata ka, karajo, balanjo, jan, juo, dan mande.

(D01) Laloklah nak, lalok babuwai Piciangan mato mande buwai

Jan manangih juo nak

Mande ka pai karajo nak

'Tidurlah nak, tidur berayun

Pejamkan mata ibu ayun

Jangan menangis juga nak

Ibu mau pergi kerja nak'

Aliterasi adalah pengulangan huruf mati pada beberapa suku kata yang berturut-turut. Pada teks Laloklah Nak Kanduang (D01) di atas dapat dilihat pengulangan bunyi yang dominan, yaitu bunyi $\mathbf{l}, \mathbf{m}, \mathbf{d a n} \mathbf{j}$ dalam beberapa baris pada kata lalok, mande, dan juo.

(D04) Kalau urang pamaleh nak

Banyak urang nan ndak suko

Kok alah gadang nak

Jan lupo isuak cari karajo

'Kalau orang pemalas nak

Banyak orang yang tidak suka

Kalau sudah besar nak

Jangan lupa besok cari kerja'

Asonansi adalah pengulangan suara vokal untuk membua rima internal. Pada teks Laloklah Nak Kanduang (D04) di atas terdapat asonansi u dan k pada kata kalau, dan urang. Pada teks nyanyian rakyat (lullaby) Laloklah Nak Kanduang terdapat beberapa bunyi kakafoni dan efoni. Kakafoni dan efoni adalah pemanfaatan bunyi sedemikian rupa sehingga bunyi yang dirangkaikan di dalam sajak dapat menimbulkan kesan yang cerah serta kesan yang sedih atau buram. Contoh bunyi kakafoni dan efoni pada teks nyanyian rakyat (lullaby) Laloklah Nak Kanduang dapat dilihat sebagai berikut.

(D01) Laloklah nak, lalok babuwai

Jan manangih juo nak

Piciangan mato mande buwai

Mande ka pai karajo nak

'Tidurlah nak, tidur berayun

Jangan menangis juga nak

Pejamkan mata ibu ayun

Ibu mau pergi kerja nak' 
Pada teks nyanyian rakyat (lullaby) Laloklah Nak Kanduang terdapat kakafoni. Kakafoni merupakan pengulangan bunyi konsonan yang menciptakan perasaan jiwa tertekan, gelisah, bahkan memuakkan. Pada teks (D01) adalah kakafoni. seorang ibu yang mendiamkan anaknya yang sedang menangis karena si ibu akan pergi bekerja dengan perasaan gelisah.

(05)Laloklah nak kanduang mande

Laloklah nak, lalok babuwai

Jikok tajago usah cari mande

Bamain sajo, mande lah pai mancari piti

'Tidurlah nak kandung ibu

Tidurlah nak, tidur berayun

Jika bangun jangan cari ibu

Bermain saja, ibu sudah pergi cari uang'

Pada teks nyanyian rakyat (lullaby) Laloklah Nak Kanduang terdapat kesan efoni. Efoni merupakan kesan dalam bait yang memilki suasana cerah, kesan yang membangkitkan kegembiraan dan rasa riang serta nyaman. Pada teks (D05) adalah efoni karena suasa dalam lariknya digambarkan suasana tenang dan nyaman.

Pada teks nyanyian rakyat (lullaby) Laloklah Nak Kanduang terdapat pengulangan unsur bunyi anafora dan pengulangan unsur bunyi epifora. Dapat dilihat pada contoh berikut ini.

(D03) Jan manangih juo

Urang panangih lambek gadangnyo

Kalaulah gadang

Jan jadi anak nan pamaleh sayang

'Jangan menangis juga

Orang penangis lambat besarnya

Kalau sudah besar

Jangan jadi anak yang pemalas sayang'

Anafora adalah pengulangan bunyi dalam bentuk kata yang sama dalam teks pada awal lariknya. Pada teks nyanyian rakyat (lullaby) Laloklah Nak Kanduang di atas terdapat pengulangan bunyi anafora. Pada teks (D03) terdapat pengulangan bunyi jan di awal lariknya.

(D05) Laloklah nak kanduang mande

Laloklah nak, lalok babuwai

Jikok tajago usah cari mande

Bamain sajo, mande lah pai mancari piti

'Tidurlah nak kandung ibu

Tidurlah nak, tidur berayun

Jika bangun jangan cari ibu

Bermain saja, ibu sudah pergi cari uang'

Epifora adalah pengulangan bunyi dalam bentuk kata yang sama dalam teks pada akhir lariknya. Pada teks nyanyian rakyat (lullaby) Laloklah Nak Kanduang di atas terdapat pengulangan bunyi epifora. Pada teks (D05) terdapat pengulangan bunyi mande pada baris pertama dan terakhir. 


\section{Struktur Batin Nyanyian Rakyat Senandung (Lullaby) Laloklah Nak Kanduang}

\section{Pola Asosiasi}

Asosiasi mempunyai kekuatan besar untuk membangkitkan emosi. Kekuatan ini berperan penting untuk memberikan efek ataupun pengaruh kepada pembaca. Asosiasi adalah media memainkan emosi dari pendengar maupun pembaca. Asosiasi dapat juga dikatakan sebagai pikiran yang muncul. Pada teks nyanyian rakyat (lullaby) Laloklah Nak Kanduang dapat dilihat pola asosiasi yang menimbulkan rasa senang atau bahagia. Contoh teks sebagai berikut.

(D03) Jan manangih juo

Urang panangih lambek gadangnyo

Kalaulah gadang

Jan jadi anak nan pamaleh sayang

'Jangan menangis juga

Orang penangis lambat besarnya

Kalau sudah besar

Jangan jadi anak yang pemalas sayang'

Pada (D03) baris ke tiga dan ke empat terdapat kata Kalaulah gadang Jan jadi anak nan pamaleh sayang berupa harapan dan doa ibu tehadap anak. Maksud dari baris ke tiga dan keempat adalah ibu berharap agar anaknya setelah besar nanti tidak menjadi anak yang pemalas.

\section{Pola Citraan dan Emosi}

Pada hakikatnya, citraan atau pengimajian ini masih berkaitan dengan permasalahan diksi. Hasanuddin WS (2002:117) terdapat lima citraan (a) citraan penglihatan, (b) citraan pendengaran, (c) citraan rasaan, (d) citraan rabaan, dan (e) citraan gerak. Pemelilhan terhadap kata tertentu akan menyebabkan timbulnya daya saran yang menyebabkan daya bayang pembaca terhadap suatu hal. Daya bayang tentu saja tergantung kepada kepmampuan masing-masing pembaca. Hasanuddin WS (2002, p. 110) mengatakan bahwa penyair berusaha mengkongkretkan ide yang abstrak. Ia berusaha menghubungkan intuisnya sebagai penyair dengan imajinasi yang ada pada pembaca. Pada akhirnya ia haus berusaha menata kata sedemikian rupa sehingga makna-makna abstrak menjadi kongkret dan nyata.

\section{a. Citraan Penglihatan}

(D02) Laloklah nak, lalok babuwai Capeklah gadang nak ooo

Usah banyak parangai

Alah mande buwai pulo

'Tidurlah nak, tidur berayun

Cepatlah besar nak ooo

Jangan banyak tingkah laku

Sudah ibu ayun pula'

Citraan penglihatan mampu memberikan rangsangan kepada indra penglihatan pembaca. Pada teks di atas pelantun menggunakan kata-kata yang dapat menimbulkan imajinasi yang kuat 
bagi pembaca dan pendengar. Kata-kata yang dipilih penyair seakan menghipnotis pendengar dan pembaca. Pada teks (D02) terdapat pola citraan penglihatan yang akan membuat pembaca atau mendengar seolah-olah dapat melihat peristiwa yang sesungguhnya.

\section{b. Citraan Pendengaran}

(D06) Usah manangih

Beko mande pulang juo

'Jangan menangis

Nanti ibu pulang juga'

Citraan pendengaran adalah citraan yang mampu merangsang pembaca dengan cara mendeskripsikan hal-hal yang berkaitan dengan indra pendengaran seperti bunyi-bunyi tertentu. Pada teks nyanyian rakyat (lullaby) Laloklah Nak Kanduang di atas pada teks (D06) termasuk citraan pendengaran, karena setiap larik pada bait di atas mampu mendeskripsikan bunyi atau pendengaran melalui doa-doa dan harapan yang ada pada teks.

\section{c. Citraan Rasaan}

(D03) Jan manangih juo

Urang panangih lambek gadangnyo

Kalaulah gadang

Jan jadi anak nan pamaleh sayang

'Jangan menangis juga

Orang penangis lambat besarnya

Kalau sudah besar

Jangan jadi anak yang pemalas sayang'

Pada data di atas terdapat citraan rasaan ketika mendengar nyanyian tersebut. Pendengar dapat merasakan apa yang dirasakan oleh pelantun. Pemilihan kata menunjukkan perasaan pelatun sehingga pendengar juga merasakan apa yang dialaminya. Pada teks (D03) adalah citraan rasaan, dimana pembaca atau pendengar seolah-olah ikut serta merasakan rasa sedih dan harapan besar yang dilantunkan oleh penyair.

\section{d. Citraan Rabaan}

(D02) Laloklah nak, lalok babuwai

Capeklah gadang nak ooo

Usah banyak parangai

Alah mande buwai pulo

'Tidurlah nak, tidur berayun

Cepatlah besar nak ooo

Jangan banyak tingkah laku

Sudah ibu ayun pula'

Citraan rabaan adalah citraan yang mampu merangsang pendengar seolah-olah dapat meraba sesuatu yang diekspresikan pelantun dalam lariknya. Pada teks (D02) erdapat larik yang 
mampu membuat pendengar seolah-olah ikut meraba kepala dan punggung anak seperti yang dilakukan penyair.

\section{e. Citraan Gerak}

(D02) Laloklah nak, lalok babuwai

Capeklah gadang nak ooo

Usah banyak parangai

Alah mande buwai pulo

'Tidurlah nak, tidur berayun

Cepatlah besar nak ooo

Jangan banyak tingkah laku

Sudah ibu ayun pula'

Citraan gerak adalah citraan yang mampu membuat pendengar atau pembaca ikut merasakan apa yang dilantunkan oleh penyair. Pada (D02) terdapat citraan gerak dimana pembaca atau pendengar seolah-olah sedang mengayun anak dan seolah-olah ikut serta dalam setiap gerakannya.

\section{f. Tema dan Amanat}

Tema adalah sesuatu pendorong pengarang untuk menciptakan puisi atau syair, mungkin bermaksud menyampaikan pesan, atau bahkan pengalaman pribadi. Sedangkan amanat adalah suatu pesan moral atau nasehat yang disampaikan dalam sebuah syair. Pada teks nyanyian rakyat (lullaby) Laloklah Nak Kanduang masyarakat di Nagari Paninggahan Kecamatan Junjung Sirih Kabupaten Solok memiliki tema dan nasehat, yaitu kemanusiaan, cinta kasih (seorang ibu kepada anaknya), dan kritik sosial.

\section{i. Kemanusiaan}

(D04) Kalau urang pamaleh nak

Banyak urang nan ndak suko

Kok alah gadang nak

Jan lupo isuak cari karajo

'Kalau orang pemalas nak

Banyak orang yang tidak suka

Kalau sudah besar nak

Jangan lupa besok cari kerja'

Pada teks (D04) di atas terdapat tema kemanusiaan. Hal tersebut tersebut dapat kita lihat bahwa seorang ibu yang merayu anaknya untuk tidak jadi anak yang pemalas.

\section{ii. Cinta Kasih (Seorang Ibu kepada Anaknya)}

(D03) Jan manangih juo

Urang panangih lambek gadangnyo

Kalaulah gadang

Jan jadi anak nan pamaleh sayang 


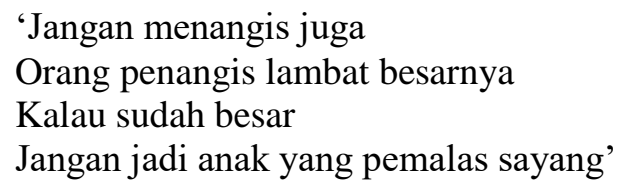

Pada teks (D03) nyanyian rakyat (lullaby) di atas bertemakan cinta kasih seorang ibu terhadap anaknya. Dapat dilihat pada cara ibu menyuruh anaknya yang sedang menangis untuk diam.

\section{iii. Kritik Sosial}

(D03) Jan manangih juo

Urang panangih lambek gadangnyo

Kalaulah gadang

Jan jadi anak nan pamaleh sayang

'Jangan menangis juga

Orang penangis lambat besarnya

Kalau sudah besar

Jangan jadi anak yang pemalas sayang'

Pada teks nyanyian rakyat (lullaby) di atas (D03) bertemakan mengenai kritik sosial. Hal tersebut dapat dilihat pada baris pertama seorang ibu yang melarang anaknya menangis karena dia ingin pergi bekerja.

\section{Fungsi Sosial Nyanyian Rakyat Senandung (Lullaby) Laloklah Nak Kanduang}

\section{Sarana Kreatif}

Kreatif adalah suatu pekerjaan yang menginginkan kepintaran dalam memutar imajinasi. Dalam data larik nyanyian rakyat (Lullaby) Laloklah Nak Kanduang memiliki fungsi kreatif. Fungsi kreatif tersebut berfungsi juga untuk pendengar maupun pembaca. Berikut contohnya.

(D01) Laloklah nak, lalok babuwai

Piciangan mato mande buwai

Jan manangih juo nak

Mande ka pai karajo nak

'Tidurlah nak, tidur berayun

Pejamkan mata ibu ayun

Jangan menangis juga nak

Ibu mau pergi kerja nak'

Pada teks (D01) dapat dilihat pemilihan kata yang kreatif dalam sebuah larik merupakan suatu bentuk kekreatifan masyarakat. Dari pemilihan kata yang mengungkapkan harapan orangtua terhadap anaknya. 


\title{
2. Pembangkit Semangat
}

Nyanyian dapat menjadi media penyemangat bagi diri sendiri dan memberikan semangat karena adanya suatu keinginan dan cita-cita, sehingga tidak sengaja dilantunkan di dalam syair. Masyarakat akan mengutarakan isi hatinya dalam nyanyian rakyat (lullaby) Laloklah Nak Kanduang, masyarakat mempercayai setiap larik yang diucapkan bias menjadi doa. Sehingga para ibu yang menyanyikan Laloklah Nak Kanduang mengutarakan doa-doa dan harapan kepada anaknya, sehingga membuat si ibu bersemangat dalam melantunkannya. Terlihat pada lirik di bawah ini.

(D02) Laloklah nak, lalok babuwai

Capeklah gadang nak ooo

Usah banyak parangai

Alah mande buwai pulo

'Tidurlah nak, tidur berayun

Cepatlah besar nak ooo

Jangan banyak tingkah laku

Sudah ibu ayun pula'

Pada teks (D03) di atas terdapat kata-kata yang mengandung doa dan harapan ibu kepada anaknya, sehingga pelatun maupun pendengar akan bersemangat mendegar nyanyiannya karena harapanharapan baik tersebut bias menjadi doa bagi anaknya.

\section{Harapan dan Doa}

Melalui nyanyian rakyat, penelti menemukan harapan dan doa yang terdapat dalam nyanyian rakyat (lullaby) Laloklah Nak Kanduang. Harapan tersebut bertujuan kepada hal-hal baik yang ditujukan kepada anaknya, baik itu rezeki, dan budi pekerti yang baik. Dengan harapan dan doa yang dilantunkan, orang tua memiliki harapan lebih kepada anaknya. Karena pada umumnya, seluruh orang tua menginginkan yang terbaik untuk anaknya. Berikut contoh fungsi sebagai harapan dan doa.

\author{
(D04) Kalau urang pamaleh nak \\ Banyak urang nan ndak suko \\ Kok alah gadang nak \\ Jan lupo isuak cari karajo \\ 'Kalau orang pemalas nak \\ Banyak orang yang tidak suka \\ Kalau sudah besar nak \\ Jangan lupa besok cari kerja'
}

Pada teks nyanyian rakyat (lullaby) terdapat doa dan harapan, dapat dilihat pada (D04) berupa harapan dan doa orang tua kepada anaknya agar menjadi anak pekerja keras, baik budi pekerti, agar bias merubah nasibnya menjadi yang lebih baik lagi.

\section{Penutup}

Berdasarkan uraian dan penjelasan di atas, dapat disimpulkan bahwa struktur nyanyian rakyat (lullaby) Laloklah Nak Kanduang masyarakat Nagari Paninggahan Kecamatan Junjung Sirih Kabupaten Solok berjumlah dua puluh dua baris yang terdiri dari enam bait. Unsur bunyi 
pada teks nyanyian rakyat (lullaby) Laloklah Nak Kanduang masyarakat Nagari Paninggahan Kecamatan Junjung Sirih Kabupaten Solok ialah rima yang berpola ab-ab, aa-bb dan aa-aa. Kemudian terdapat pula aliterasi dan asonansi, kakafoni dan efoni, anaphora dan epifora. Ini dikarnakan larikknya emiliki pengulangan kata di awal, tengah, maupun di akhir kalimat. Kemudian larik dari nyanyian rakyat ini menggambarkan kesedihan dan kebahagian seorang ibu terhadap anaknya.

Adapun struktur batin pada nyanyian rakyat (lullaby) Laloklah Nak Kanduang masyarakat Nagari Paninggahan Kecamatan Junjung Sirih Kabupaten Solok ialah 1) pola asosiasi yang digunakan dalam nyanyian rakyat yaitu asosiasi yang menimbulkan perasaan yang menyenangkan, 2) pola-pola citra dan emosi nyanyian rakyat lullaby adalah citra penglihatan, pendengaran, rasaan, rabaan, dan gerak. 3) tema yang terdapat dalam teks nyanyian rakyat yaitu tema kemanusiaan, cinta kasih (ibu kepada anaknya), dan kritik sosial.Fungsi sosial nyanyian rakyat Laloklah Nak Kanduang masyarakat Nagari Paninggahan Kecamatan Junjung Sirih Kabupaten Solok ialah 1) sarana kreatif, 2) pembangkit semangat,3) harapan dan doa-doa seorang ibu kepada anaknya.

\section{Referensi}

Badan Pusat Statistik Kabupaten Solok. (2017). Kecamatan Junjung Sirih dalam Angka 2017. Kabupaten Solok: Badan Pusat Statistik Kabupaten Solok.

Danandjaya. J. (1991). Folklor Indonesia: ilmu gosip, dongeng, dan lain-lain. Jakarta: Grafiti Press.

Fitriani, R. (2020). "Struktur dan Fungsi Sosial Nyanyian Rakyat Senandung (Lullaby) Ende Buebue Masyarakat Desa Sarimanaon Kecamatan Angkola Muara Tais Kabupaten Tapanulis Selatan.” Skripsi. Fakultas Bahasa dan Seni Universitas Negeri Padang.

Hasanuddin WS, Emidar, Zulfadhli. (2020). "Social Function of The Text of Oral tradition of Lullaby Song Coastal Region of the Minangkabau Collective in West Sumatera". In International Conference Language and Art (ICLA 2020)on october 14-15, Padang, Indonesia.

Hasanuddin WS, Emidar, Zulfadhli. (2020). "Text Of Oral Tradition Of Lullaby Songs Mainland Region Of the Minangkabau Collective: Format, Conten and Functions" in proceeding international conference Language, Literature and educations (ICLLE 2020) on Agust 12-13, Padang, Anvanced in Sosial Science, Educatin and Humanities Research, Volume 485, ISBN 978-94-6239-6239-271-7, ISSN 2352-5398, DOI https://10.2991/asser.k.201109.025, Published by Atlantis Press.

Hasanuddin WS, Emidar, Zulfadhli. (2020). "Social Function Of The Text Of Oral Tradition Of Lullaby Songs Coastal Region Of The Minangkabau Collective In West Sumatra". In International Conference Language And art (ICLA 2020) on October 14-15, Padang, Indonesia.

Hasanuddin WS. (2002). Membaca dan Menilai Sajak. Bandung: Angkasa.

Nazir. (1988). Metode Penelitian. Jakarta: Ghalia Indonesia.

Saryono. (2010). Metodologi Penelitian Kualitatif. Yogyakarta: Mitra Cendikia. 
Teeuw, A. (1989). Sastra Indonesia Modern. Jakarta: Pustaka Jaya. 